\section{(2) \\ BRAZIULIAN JOURNAL \\ OF MEDICAL AND BIOLOGICAL RESEARCH}

www.bjournal.com.br
ISSN 1414-431X

Volume 45 (11) 995-1101 November 2012

BIOMIDICAL SCIENCES

AND

CLINICAL INVESTIGATION

Braz J Med Biol Res, November 2012, Volume 45(11) 1011-1016

doi: 10.1590/S0100-879X2012007500129

Role of p53 codon 72 polymorphism in chromosomal aberrations and mitotic index in patients with chronic hepatitis B

H. Akbaş, K. Yalcin, H. Isi, S. Tekes, A.E. Atay, Z. Akkus and T. Budak

The Brazilian Journal of Medical and Biological Research is partially financed by

\section{Q QNPPq}

da Ciência e Tecnologia

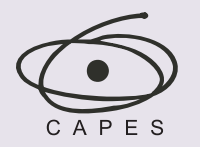

Ministério da Educação

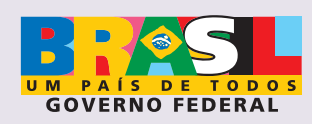

DTAPESP

Institutional Sponsors

† SHIMADZu

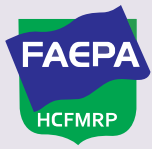

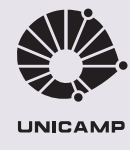

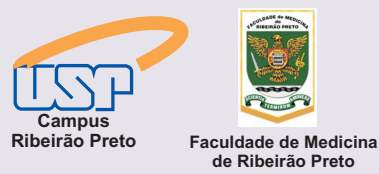

de Ribeirão Preto
de 


\title{
Role of p53 codon 72 polymorphism in chromosomal aberrations and mitotic index in patients with chronic hepatitis B
}

\author{
H. Akbaş ${ }^{1}$, K. Yalcin², H. Isi' ${ }^{3}$, S. Tekes ${ }^{3}$, A.E. Atay ${ }^{4}$, Z. Akkus ${ }^{5}$ and T. Budak ${ }^{3}$ \\ ${ }^{1}$ Department of Medical Biology, Medical Faculty, University of Harran, Şanlıurfa, Turkey \\ ${ }^{2}$ Department of Gastroenterology, Medical Faculty, University of Dicle, Diyarbakır, Turkey \\ ${ }^{3}$ Department of Medical Biology, Medical Faculty, University of Dicle, Diyarbakır, Turkey \\ ${ }^{4}$ Department of Internal Medicine, Family Medical Center, Diyarbakir, Turkey \\ ${ }^{5}$ Department of Biostatistics, Medical Faculty, University of Dicle, Diyarbakır, Turkey
}

\begin{abstract}
Polymorphisms of the p53 gene, which participates in DNA repair, can affect the functioning of the p53 protein. The Arg and Pro variants in $\mathrm{p} 53$ codon 72 were shown to have different regulation properties of p53-dependent DNA repair target genes that can affect various levels of cytogenetic aberrations in chronic hepatitis B patients. The present study aimed to examine the frequency of chromosomal aberrations and the mitotic index in patients with chronic hepatitis $B$ and their possible association with p53 gene exon 4 codon 72 Arg72Pro (Ex4+119 G>C; rs1042522) polymorphism. Fifty-eight patients with chronic hepatitis $B$ and 30 healthy individuals were genotyped in terms of the p53 gene codon 72 Arg72Pro polymorphism by PCR-RFLP. A 72-h cell culture was performed on the same individuals and evaluated in terms of chromosomal aberrations and mitotic index. A high frequency of chromosomal aberrations and low mitotic index were detected in the patient group compared to the control group. A higher frequency of chromosomal aberrations was detected in both the patient and the control groups with a homozygous proline genotype (13 patients, 3 control subjects) compared to patients and controls with other genotypes [Arg/Pro (38 patients, 20 control subjects) and Arg/Arg (7 patients, 7 control subjects)]. We observed an increased frequency of cytogenetic aberrations in patients with chronic hepatitis B. In addition, a higher frequency of cytogenetic aberrations was observed in p53 variants having the homozygous proline genotype compared to variants having other genotypes both in patients and healthy individuals.
\end{abstract}

Key words: Hepatitis B; Chromosomal aberrations; Mitotic index; p53 gene codon 72 polymorphism

\section{Introduction}

Hepatitis $B$ virus (HBV) is the major cause of chronic hepatitis, cirrhosis and hepatocellular carcinoma (HCC) worldwide and ranks 10th among leading causes of death (1 million deaths/year) $(1,2)$. Chronic HBV infection is characterized by a necroinflammatory process involving inflammation and liver regeneration $(3,4)$. Hepatocarcinogenesis is a multistep process influenced by oncogenes and tumor suppressor genes (5). The complex role of HBV in liver carcinogenesis through direct and indirect mechanisms is being debated. Integration of HBV-DNA sequences into the host cell genome can activate cellular genes by a cis-acting mechanism. Chromosomal instability may also result from HBV-DNA integration. HBV-DNA integration into the host cell genome can lead to increased frequencies of chromosomal instability and genetic recombinations (6).
Cytogenetic instability of immune system cells in chronic viral infections has been associated with inhibition of the DNA excision repair system and disregulation of apoptosis in target cells (7).

The polymorphisms of genes regulating the DNA repair mechanism and apoptosis affect the baseline level of cytogenetic biomarkers such as chromosomal aberrations (8). Specific mutations of the p53 gene have been strongly implicated in a variety of human cancers (9). The p53 gene representing the key regulator of apoptosis and DNA repair mechanism is of critical importance for the regulation of the cell cycle and the maintenance of genomic integrity. Loss of p53 function has been suggested to be a critical step in multistage hepatocarcinogenesis (10). It is likely that gene polymorphisms can influence p53-related DNA

Correspondence: H. Akbaş, Department of Medical Biology, Medical Faculty, University of Harran, Şanlıurfa 63100, Turkey.

E-mail: ehves@mynet.com

Received March 15, 2012. Accepted July 19, 2012. Available online August 17, 2012. Published October 5, 2012. 
damage repair and thus provoke chromosome aberrations and decrease mitotic index.

One of the well-known polymorphisms of the p53 gene is Arg72Pro in codon 72 of exon 4 (Ex4+119 G>C; rs1042522), which encodes an arginine-proline substitution in the p53 protein. Two polymorphic variants of wild-type p53 protein have been shown to have some different biochemical and biological properties (11). It has been reported that the Arg variant induces apoptosis more effectively than the Pro variant, which may influence cancer risk (12). The Pro variant has been identified as a risk factor for some malignancies including HCC, but the relationship between this polymorphism and the outcome of HBV infection has not been firmly established (13-15).

Considering all of the above facts, the objective of the present study was to investigate whether there is an association between the mitotic index and chromosomal aberrations and the p53 gene codon 72 Arg72Pro polymorphism in patients with chronic hepatitis $\mathrm{B}$ compared to a control group.

\section{Subjects and Methods}

\section{Subjects}

Fifty-eight hepatitis B patients receiving interferon therapy in the Department of Gastroenterology, Medical School of Dicle University, were enrolled in the study. Patients with positive hepatitis B surface antigen ( $\mathrm{HbsAg}$ ) and negative hepatitis $B$ antibody (AntiHbs) for more than 6 months were enrolled. Patients with persistently elevated levels of alanine aminotransferase and HBV-DNA received peg-IFN alpha-2a (180 $\mu$ g/week, Pegasys ${ }^{\circledR}$, Roche, Switzerland) subcutaneously or peg-IFN alpha-2b $\left(1.5 \mu \mathrm{g} \cdot \mathrm{kg}^{-1} \cdot\right.$ week $^{-1}$, Pegintron ${ }^{\circledR}$, Schering, Puerto Rico) subcutaneously. Blood samples were obtained before initiating the treatment. The control group consisted of 30 age- and gender-matched healthy individuals. Patients and controls with any accompanying metabolic or hormonal disorders including hepatosteatosis, hyper- or hypothyroidism, or hyperprolactinemia were excluded. Patients and controls were residents of the same area and came from the same human subpopulation.

An informed consent was obtained from the patients and control subjects. The Dicle University Medical Faculty Ethics Committee approved the study (\#B.30.2.DiC.0.01.00.00/49).

\section{Lymphocyte cultures and cytogenetic analysis}

For each subject, two whole blood cultures were incubated for $72 \mathrm{~h}$ at $37^{\circ} \mathrm{C}$ in RPMI 1640 medium supplemented with $20 \%$ fetal bovine serum, $100 \mathrm{IU} / \mathrm{mL}$ penicillin $\mathrm{G}$ and $100 \mu \mathrm{g} / \mathrm{mL}$ streptomycin. Lymphocyte growth was stimulated with $1 \%$ phytohemagglutinin (16). Colchicine (final concentration $0.06 \mathrm{mg} / \mathrm{mL}$ ) was added to the cultures $2 \mathrm{~h}$ before harvesting time. Subsequently, cells were subjected to a hypotonic solution $(0.55 \% \mathrm{KCl})$ and fixed with ethanol/glacial acetic acid (3:1). Routine chromosome staining was performed with Giemsa in phosphate buffer. Forty Giemsa-stained metaphases were scored for the percentages of chromosome breaks and chromatid breaks. Chromosome breaks, fragments and deletions were scored as 1; translocation, dicentric chromosomes and rings were scored as 2. Gaps were not included $(17,18)$. Representative metaphase spreads of the above chromosomal aberrations are shown in Figure 1. For the mitotic index values, the percentage of metaphases was assessed in 1000 blast nuclei (19).

\section{DNA extraction and polymorphism detection}

Genomic DNA was isolated from peripheral leukocytes. The blood samples were submitted to digestion in SDS/ proteinase $\mathrm{K}$ buffer at $37^{\circ} \mathrm{C}$ for $6-12 \mathrm{~h}$, followed by two phenol extractions and one chloroform extraction. DNA was then ethanol-precipitated and resuspended in Tris$\mathrm{HCl}$-EDTA buffer (20).

A modified method of polymerase chain reactionrestriction fragment length polymorphism (PCR-RFLP) originally described by Kawajiri et al. (21) was used to identify the p53 gene polymorphism at codon 72 in exon 4 using primers (5'-ATCTACAGTCCCCCTTGCCG-3') and (5'-GCAACTG ACCGTGCAAGTCA-3') (15,21). The PCR was performed at $94^{\circ} \mathrm{C}$ for 4 min to induce initial denatur-

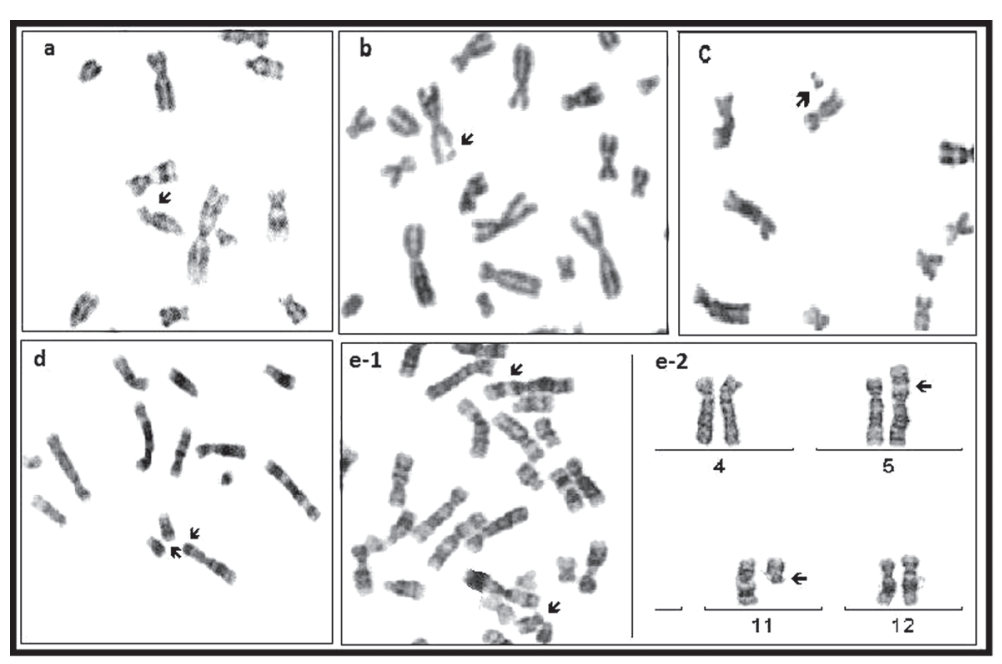

Figure 1. Representative chromosome aberrations (arrows) in metaphase spreads. $a$, Chromatid break; $b$, chromatid gap; $c$, acentric fragment; $d$, deletion of chromosome 2q; e-1, partial metaphase of translocation between chromosomes 5 and 11; e-2, partial karyotype of translocation between chromosomes 5 and 11. 
ation, followed by 35 cycles of $40 \mathrm{~s}$ at $94^{\circ} \mathrm{C}$, $30 \mathrm{~s}$ at $56^{\circ} \mathrm{C}$, and $30 \mathrm{~s}$ at $72^{\circ} \mathrm{C}$, with a final extension at $72^{\circ} \mathrm{C}$ for $10 \mathrm{~min}$. This generated a 296-bp fragment that was then subjected to digestion with Bsh1236I (Fermentas Life Science, Germany) overnight at $37^{\circ} \mathrm{C}$. The digested product was visualized on $3 \%$ agarose gel, followed by ethidium bromide staining. The presence of the wild-type allele $(A r g)$ was indicated by bands of 169 and $127 \mathrm{bp}$, whereas no digestion of the mutant allele (Pro) occurred. The sample image of PCR-RFLP products belonging to the aforementioned polymorphism obtained by agarose gel electrophorese is presented in Figure 2.

\section{Statistical analysis}

Data are reported as means $\pm S D$ and statistical analyses were performed using

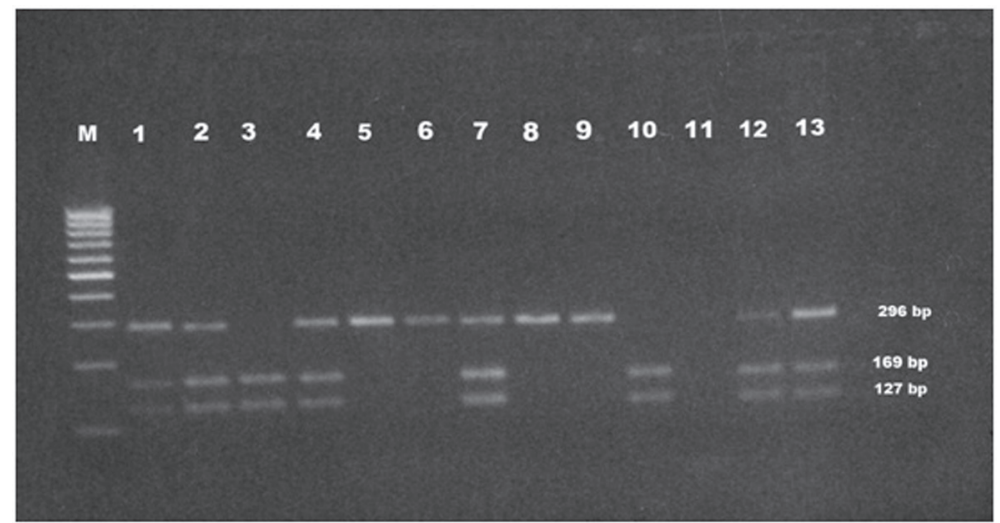

Figure 2. PCR-RFLP products belonging to the polymorphism of $p 53$ gene codon 72 obtained by agarose gel electrophoresis. Homozygous proline genotype $=\mathrm{a}$ single band of 296 bp (lanes 5, 6, 8, and 9); homozygous arginine genotype = two bands of 169 and 127 bp (lanes 3 and 10); heterozygous arginine/proline genotype = three bands of 296, 169, and $127 \mathrm{bp}$ (lanes 1, 2, 4, 7, 12, and 13). M = 100-bp DNA marker; lane 11 = negative amplification product. the SPSS Statistical package, version 11.5 for Windows (SPSS. Inc., USA). The normality of distribution was evaluated by the Kolmogorov-Smirnov test and the normally distributed data were analyzed by the Student $t$-test. Non-normally distributed data were analyzed by the chi-square test. All statistical tests were two-sided, and a $\mathrm{P}$ value $<0.05$ was considered to be statistically significant.

\section{Results}

Fifty-eight patients with chronic hepatitis $B, 38$ males and 20 females, and 30 healthy individuals, 18 males and 12 females, were enrolled in the study. The mean ages of the patient and the control groups were $35.03 \pm 13.76$ and $36.23 \pm 13.55$, respectively. No statistically significant difference in age or gender distribution was observed between the patient and the control groups $(P>0.05)$. The demographic characteristics of the study group are listed in Table 1.

The frequency of chromosomal aberrations was significantly higher and the mean mitotic index was significantly lower in the patient group compared to the control group $(P<0.05$ and $P<0.05$, respectively). The mean frequencies of chromosomal aberrations and the mitotic index of patients with chronic hepatitis B and of the control group are shown in Table 2.

No significant difference was detected between the patient and the control groups in terms of genotype distribution $\left(X^{2}=3.26 ; P>0.05\right)$.

The mean frequencies of chromosomal aberrations in control individuals and patients with the homozygous proline (Pro/Pro) genotype and other genotypes (Arg/Pro and Arg/Arg) are shown in Table 3. A significant difference was observed between participants with the homozygous proline genotype and the other genotypes (Arg/Pro and Arg/Arg) in
Table 1. Demographic characteristics of the study group.

\begin{tabular}{lcc}
\hline & $\mathrm{N}$ & Age, years (means $\pm \mathrm{SD}$ ) \\
\hline Patient group & & \\
$\quad$ Female & 20 & $36.2 \pm 16.2$ \\
$\quad$ Male & 38 & $34.5 \pm 12.5$ \\
Control group & & \\
$\quad$ Female & 12 & $37.1 \pm 15.4$ \\
Male & 18 & $35.7 \pm 12.6$ \\
\hline
\end{tabular}

There were no statistical differences between groups (Student $t$-test).

Table 2. Comparison of patients and controls in terms of chromosomal aberrations and mitotic index.

\begin{tabular}{lrc}
\hline & Patient & Control \\
\hline Mitotic index & $1.99 \pm 0.93^{*}$ & $3.15 \pm 1.29$ \\
Chromosomal aberrations & $2.4 \pm 0.85^{\star}$ & $0.83 \pm 0.21$ \\
\hline
\end{tabular}

${ }^{*} \mathrm{P}<0.05$ compared to control group (Student $t$-test).

terms of chromosomal aberrations in both the patient and the control groups $(P<0.05)$. However, no significant difference in mitotic index was observed between individuals with the homozygous proline genotype and the other genotypes (Arg/Pro and Arg/Arg) in either group ( $P$ > 0.05).

\section{Discussion}

There is increasing evidence that HBV infection can cause genetic changes within somatic cells, including he- 
Table 3. Chromosomal aberrations observed in patients and control individuals with the homozygous proline genotype (Pro/ Pro) and other genotypes (Arg/Pro and Arg/Arg).

\begin{tabular}{lrc}
\hline & $\mathrm{N}$ & Chromosomal aberrations \\
\hline Patient & & \\
Pro/Pro & 13 & $7.31 \pm 2.57^{*}$ \\
Arg/Pro & 38 & $3.16 \pm 0.80$ \\
Arg/Arg & 7 & $4.29 \pm 4.28$ \\
Control & & \\
Pro/Pro & 3 & $3.33 \pm 2.88^{*}$ \\
Arg/Pro & 20 & $0.25 \pm 0.24$ \\
Arg/Arg & 7 & $1.43 \pm 0.92$ \\
\hline
\end{tabular}

Data are reported as means $\pm S D$. ${ }^{*} P<0.05$, Pro/Pro compared to Arg/Pro and Arg/Arg (Student $t$-test).

patocytes and blood cells, as demonstrated by increased chromosomal breakage, sister chromatid exchange and decreased mitotic index $(22,23)$. The HBV genome can integrate into the host genome; these non-specific integrations exist within different regions, leading to chromosomal instability (23). HBV-DNA integrations are targeted not only in host hepatocyte genomes but also in other cells known to carry HBV, such as blood cells. Integrations increase chromosomal instability and cause genetic recombinations and particularly hepatocellular carcinogenesis $(6,24,25)$.

A higher frequency of sister chromatid exchange and a lower mitotic index were observed in the peripheral lymphocytes of patients with chronic HBV infection or cirrhosis. It has been suggested that this is the result of direct genotoxic effects of HBV and genotoxicity may contribute to the development of hepatocellular carcinoma (26).

We observed a high frequency of chromosomal aberrations and low mitotic index in the peripheral lymphocytes of patients with chronic hepatitis $B$. This result supports the view that HBV has genotoxic and apoptotic effects on the host genome.

Although the rate of chromosomal aberrations was very low in the control group, advanced age was proposed as the major causative factor in the development of chromosomal aberrations in these healthy individuals. Aging is related to an increased frequency of genomic instability and changes in chromosome morphology $(27,28)$. Examples of agerelated genomic instability include karyotype alterations, 2qs, deletions or losses of entire chromosomes resulting in aneuploidy (29). The age-related increase in chromosomal abnormalities may be further mediated by accumulated mutations in genes coding proteins required for DNA replication and repair and checkpoints and by epigenetic effects on macromolecules and mechanisms responsible for genome maintenance (30).

The influence of gene polymorphisms, particularly those related to DNA repair, on the frequency of chromosome aberrations is becoming constantly more apparent. The protective or predisposing role of certain DNA repair genes regarding chromosome aberrations has been observed $(31,32)$. The influence of polymorphisms on the p53 gene, the key regulator of the DNA repair processes, and on the frequency of chromosome aberrations is an interesting aspect. The most important polymorphism of the p53 gene in the general population, characterized by an Arg to Pro substitution at codon 72 in the transactivation domain of exon 4, has been investigated as a risk modifier in several cancer models including HCC and HBV-related HCC $(15,33)$. The variant Pro allele has been shown to be less efficient in suppressing cell transformation and inducing apoptosis and to be less sensitive to degradation by viral oncogenic proteins (11). However, other recent reports have pointed out that the Arg variant is a less efficient DNA repair molecule and therefore Arg/Arg carriers may have an increased frequency of chromosomal aberrations and a high level of genomic instability $(34,35)$.

In the present study, the genotype distribution of p53 gene codon 72 polymorphism did not differ significantly between patients and control subjects. We also observed no significant association between mitotic index and p53 gene codon 72 polymorphism. However, both in patients and healthy controls with a homozygous proline genotype, we observed higher rates of chromosomal aberrations when compared to patients and control individuals with other genotypes (Arg/Pro and Arg/Arg), which are supposed to be associated with the risk of developing HCC.

The present study has some limitations. The first was the limited number of patients who participated in the study. We performed this study in the southeastern region of Turkey where some technical and economic issues prevented us from increasing the sample size. Second, the duration of chronic HBV infection may influence the development of chromosomal aberrations. There was a wide variation in the duration of chronic HBV infection in our study. Also, homogeneity of the duration of chronic HBV infection may be of significance in determining the relationship of HBV infection with chromosomal instability. Leveri et al. (36) mentioned that variation in susceptibility to chromosomal aberrations and mitotic index is partially attributed to the duration of HBV infection as well as to the demographic characteristics of the patients such as age, gender, ethnicity, exposure to aflatoxin, cigarette smoking, and alcohol consumption. A larger number of individuals and a longer duration of follow-up are required to confirm and extend the present results.

We demonstrate that the homozygous proline variant (Pro/Pro) of p53 codon 72 has a higher susceptibility to genomic instability than homozygous arginine (Arg/Arg) and heterozygous arginine/proline (Arg/Pro) variants. However, the higher frequency of chromosomal aberrations in healthy controls with the homozygous proline genotype indicates that the Pro variant affects the occurrence of genomic instability independently from the hepatitis $B$ virus. Our results 
support the view that the Pro variant is less effective than the Arg variant in inducing apoptosis and inhibiting cellular transformation. These results agree with studies that assert that the homozygous proline genotype is directly related to

\section{References}

1. Jaroszewicz J, Calle SB, Wursthorn K, Deterding K, Schlue $J$, Raupach R, et al. Hepatitis B surface antigen (HBsAg) levels in the natural history of hepatitis B virus (HBV)-infection: a European perspective. J Hepatol 2010; 52: 514-522.

2. National Toxicology Program. Hepatitis B virus. Rep Carcinog 2011; 12: 216-218.

3. Hsieh YH, Hsu JL, Su IJ, Huang W. Genomic instability caused by hepatitis B virus: into the hepatoma inferno. Front Biosci 2011; 17: 2586-2597.

4. Mah YH, Hsu CS, Liu CH, Liu CJ, Lai MY, Chen PJ, et al. Serum p53 gene polymorphisms and severity of hepatitis $\mathrm{B}$ or C-related chronic liver diseases in Taiwan. Hepatol Int 2011; 5: 814-821.

5. Nishida N, Goel A. Genetic and epigenetic signatures in human hepatocellular carcinoma: a systematic review. Curr Genomics 2011; 12: 130-137.

6. Chatterjee B, Ghosh PK. Constitutive heterochromatin polymorphism and chromosome damage in viral hepatitis. Mutat Res 1989; 210: 49-57.

7. Ryazantseva NV, Novitskii VV, Zhukova OB, Radzivil TT, Mikheev SL, Chechina OE, et al. Dysregulation of apoptotic death in the pathogenesis of virus-induced cytogenetic instability of blood lymphocytes. Bull Exp Biol Med 2006; 141: 606-609.

8. Norppa H. Cytogenetic biomarkers and genetic polymorphisms. Toxicol Lett 2004; 149: 309-334.

9. Olivier M, Petitjean A, Marcel V, Pétré A, Mounawar M, Plymoth $A$, et al. Recent advances in p53 research: an interdisciplinary perspective. Cancer Gene Ther 2009; 16: $1-12$.

10. Staib F, Hussain SP, Hofseth LJ, Wang XW, Harris CC. TP53 and liver carcinogenesis. Hum Mutat 2003; 21: 201-216.

11. Thomas M, Kalita A, Labrecque S, Pim D, Banks L, Matlashewski G. Two polymorphic variants of wild-type p53 differ biochemically and biologically. Mol Cell Biol 1999; 19: 10921100.

12. Dumont P, Leu JI, Della Pietra AC III, George DL, Murphy M. The codon 72 polymorphic variants of p53 have markedly different apoptotic potential. Nat Genet 2003; 33: 357-365.

13. Yoon YJ, Chang HY, Ahn SH, Kim JK, Park YK, Kang DR, et al. MDM2 and p53 polymorphisms are associated with the development of hepatocellular carcinoma in patients with chronic hepatitis B virus infection. Carcinogenesis 2008; 29: 1192-1196.

14. Kim YJ, Lee HS. Single nucleotide polymorphisms associated with hepatocellular carcinoma in patients with chronic hepatitis B virus infection. Intervirology 2005; 48: 10-15.

15. Yu MW, Yang SY, Chiu YH, Chiang YC, Liaw YF, Chen CJ. A p53 genetic polymorphism as a modulator of hepatocellular carcinoma risk in relation to chronic liver disease, familial tendency, and cigarette smoking in hepatitis B carriers. Hepatology 1999; 29: 697-702.

16. Rooney DE, Czepulkowski BH. Tissue culture methods in the development of HCC in healthy populations. Also, our results disagree with reports suggesting that the Arg form might be less potent in reducing genomic instability, and perhaps cancer predisposition (34-36). human cytogenetics. In: Rooney DE, Czepulkowski BH (Editors), Human cytogenetics - A practical approach. Washington: IRL Press; 1992. p 1-36.

17. Safai A, Vasei M, Attaranzadeh A, Azad F, Tabibi N. Chromosomal abnormality in patients with secondary amenorrhea. Arch Iran Med 2012; 15: 232-234.

18. Berger R, Le Coniat M, Gendron MC. Fanconi anemia. Chromosome breakage and cell cycle studies. Cancer Genet Cytogenet 1993; 69: 13-16.

19. Tedeschi B, Cicchetti R, Argentin G, Caporossi D, Pittaluga $M$, Parisi $P$, et al. Aphidicolin and bleomycin induced chromosome damage as biomarker of mutagen sensitivity: a twin study. Mutat Res 2004; 546: 55-64.

20. Ezzikouri S, El Feydi AE, Chafik A, Benazzouz M, El Kihal $L$, Afifi $R$, et al. The Pro variant of the p53 codon 72 polymorphism is associated with hepatocellular carcinoma in Moroccan population. Hepatol Res 2007; 37: 748-754.

21. Kawajiri K, Nakachi K, Imai K, Watanabe J, Hayashi S. Germ line polymorphisms of p53 and CYP1A1 genes involved in human lung cancer. Carcinogenesis 1993; 14: 1085-1089.

22. Ozkal $P$, Ilgin-Ruhi $H$, Akdogan $M$, Elhan $A H$, Kacar $S$, Sasmaz N. The genotoxic effects of hepatitis B virus to host DNA. Mutagenesis 2005; 20: 147-150.

23. Huang JM, Huang TH, Qiu HY, Fang XW, Zhuang TG, Liu $\mathrm{HX}$, et al. Effects of hepatitis B virus infection on human sperm chromosomes. World J Gastroenterol 2003; 9: 736740.

24. Zondervan PE, Wink J, Alers JC, IJzermans JN, Schalm SW, de Man RA, et al. Molecular cytogenetic evaluation of virus-associated and non-viral hepatocellular carcinoma: analysis of 26 carcinomas and 12 concurrent dysplasias. $J$ Pathol 2000; 192: 207-215.

25. Chen PJ, Chen DS. Hepatitis B virus infection and hepatocellular carcinoma: molecular genetics and clinical perspectives. Semin Liver Dis 1999; 19: 253-262.

26. Ucur A, Palanduz S, Cefle K, Ozturk S, Tutkan G, Vatansever $S$, et al. Sister chromatid exchange and mitotic index in patients with cirrhosis related to hepatitis $B$ and $C$ viruses and in chronic carriers. Hepatogastroenterology 2003; 50: 2137-2140.

27. Mutlu-Turkoglu U, Ilhan E, Oztezcan S, Kuru A, Aykac-Toker G, Uysal M. Age-related increases in plasma malondialdehyde and protein carbonyl levels and lymphocyte DNA damage in elderly subjects. Clin Biochem 2003; 36: 397-400.

28. Retana-Ugalde $R$, Casanueva E, Altamirano-Lozano $M$, Gonzalez-Torres C, Mendoza-Nunez VM. High dosage of ascorbic acid and alpha-tocopherol is not useful for diminishing oxidative stress and DNA damage in healthy elderly adults. Ann Nutr Metab 2008; 52: 167-173.

29. Jefford CE, Irminger-Finger I. Mechanisms of chromosome instability in cancers. Crit Rev Oncol Hematol 2006; 59: 1-14.

30. Burhans WC, Weinberger M. DNA replication stress, ge- 
nome instability and aging. Nucleic Acids Res 2007; 35: 7545-7556.

31. Kiuru A, Lindholm C, Heilimo I, Ceppi M, Koivistoinen A, llus $\mathrm{T}$, et al. Influence of DNA repair gene polymorphisms on the yield of chromosomal aberrations. Environ Mol Mutagen 2005; 46: 198-205.

32. Skjelbred CF, Svendsen M, Haugan V, Eek AK, Clausen $\mathrm{KO}$, Svendsen MV, et al. Influence of DNA repair gene polymorphisms of hOGG1, XRCC1, XRCC3, ERCC2 and the folate metabolism gene MTHFR on chromosomal aberration frequencies. Mutat Res 2006; 602: 151-162.

33. Storey A, Thomas M, Kalita A, Harwood C, Gardiol D, Mantovani $F$, et al. Role of a p53 polymorphism in the development of human papillomavirus-associated cancer. Nature 1998;
393: 229-234.

34. Siddique M, Sabapathy K. Trp53-dependent DNA-repair is affected by the codon 72 polymorphism. Oncogene 2006; 25: 3489-3500.

35. Litviakov NV, Denisov EV, Takhauov RM, Karpov AB, Skobel'skaja EV, Vasil'eva EO, et al. Association between TP53 gene ARG72PRO polymorphism and chromosome aberrations in human cancers. Mol Carcinog 2010; 49: 521524.

36. Leveri M, Gritti C, Rossi L, Zavaglia C, Civardi E, Mondelli $\mathrm{MU}$, et al. Codon 72 polymorphism of P53 gene does not affect the risk of cirrhosis and hepatocarcinoma in HCVinfected patients. Cancer Lett 2004; 208: 75-79. 